\title{
1 Phanerozoic magmatic tempos of North China
}

\section{Tim Cope}

3 Department of Geosciences

4 DePauw University

5 Greencastle, IN 46135

\section{Abstract}

7 Detrital zircons from northeast China record cyclic magmatism along the northern and eastern margins of the

8 North China block during late Paleozoic time and Mesozoic time, respectively. The late Paleozoic zircons record

9 three magmatic flare-ups with a period of $\sim 60$ m.y. that occurred within a magmatic arc constructed along the

10 Paleoasian (northern) margin of North China, and are accompanied by negative $\varepsilon_{\mathrm{Hf}}(\mathrm{t})$ excursions representing

11 shortening and increased crustal melting over the duration of each flare-up. The intervening magmatic lulls are

12 accompanied by rapid positive $\varepsilon_{\mathrm{Hf}}(\mathrm{t})$ excursions signifying influxes of juvenile magma into the arc, probably

13 during extension and foundering of underlying melt residua. The lack of similar isotopic patterns in zircons

14 derived from contemporaneous intrusions into older continental settings inboard of the arc indicate that this

15 process was restricted to the arc itself. Mesozoic magmatism in North China occurred along the Paleo-Pacific

16 margin following closure of the Paleoasian Ocean, and exhibits a $\sim 50 \mathrm{~m}$.y. periodicity that is out-of-phase with

17 that of the Paleozoic arc. Although the tectonic setting of North China during Mesozoic time is complex and still

18 controversial, it is possible that this younger periodicity is governed by similar processes as those that dominated

19 the Paleozoic arc. This is a testable hypothesis that warrants further attention. Crustal shortening was widespread

20 in North China during Mesozoic time, and documented lithosphere removal events in eastern North China

21 occurred during the Mesozoic magmatic lulls. Lithospheric thickening/foundering cyclicity, well-documented in

22 Cordilleran arc systems, may be a common process in continental arcs through space and time.

\section{1. Introduction}

24 The genesis and growth of buoyant, felsic continental crust requires some mechanism by which mafic constituents

25 of mantle melts be segregated and returned to the mantle, leaving behind continental crust of dominantly andesitic 
composition (Rudnick, 1995). One persuasive theory as to how this occurs is via segregation and density-driven

27 foundering of eclogitic lower crust or melt residue into the convecting mantle (Kay and Mahlburg-Kay, 1993).

Density-driven removal of continental lithosphere has now been implicated in a variety of tectonic settings (Gao

et al., 2004; Garzione et al., 2000; 2008; Zandt et al., 2004), but is most commonly associated with thickened

crust along convergent continental margins (Kay and Mahlburg-Kay, 1991). Magmatism along convergent

continental margins (i.e. in continental volcanic arcs) tends to occur in pulses (flare-ups or high-flux episodes)

with a regular period of between 20-60 m.y. (Paterson and Ducea, 2015). The causes of this periodicity may be internal or external to the arc. One model to explain the observed tempo of Cordilleran magmatic arcs involves the growth and periodic foundering of crustal melt residua from beneath continental arcs that are undergoing crustal thickening (DeCelles et al., 2009). A superb tracer of this process is the isotopic character of the melts over time (in most studies, initial $\varepsilon_{\mathrm{Nd}}$ ), which tracks melt sources and varies systematically with respect to each flare-up in a manner that is difficult to envision occurring in any other setting.

Models for Cordilleran magmatic cyclicity are supported by excellent control on plate tectonic boundary conditions, the timing of continental shortening events, and petrological data on igneous sources within the arc system (DeCelles et al., 2009; Paterson and Ducea, 2015). These controls are lacking in many other arc systems. However, the strong correlation between flare-ups and radiogenic isotope character in the Cordillera appears to be a defining characteristic of lithospheric thickening/foundering cyclicity, and one that would be enhanced in areas with a greater distinction between the isotopic signature of the mantle and continental melt sources involved. Because the $\varepsilon_{\mathrm{Nd}}(\mathrm{t})$ and $\varepsilon_{\mathrm{Hf}}(\mathrm{t})$ isotopic character of continental crust is age-dependent, studies of young arc systems developed on extremely old continental blocks should provide a good test of whether the correlation between flare-ups and isotopic character holds for continental arcs in other regions.

The North China block of east Asia is one of the oldest crustal blocks in the world (Zhao, 2013). This paper describes the results of a large- $\mathrm{N}(\mathrm{N}=$ number $)$ study of detrital zircon $\mathrm{U}-\mathrm{Pb}$ ages $(\mathrm{N}=4687)$ and $\varepsilon_{\mathrm{Hf}}(\mathrm{t})$ analyses $(\mathrm{N}=585)$ from the North China block that reflect the initiation, development, and destruction of a late Paleozoic volcanic arc along its northern margin. Three well-resolved flare-ups occur with a period of $\sim 60$ my and increasing intensity over the 170 m.y. lifespan of the arc, very similar to the tempo of magmatism in other 
continental arc systems. Following the extinction of this arc by closure of the Paleo-Asian Ocean (Xiao et al., 2003), a second arc system associated with Paleo-Pacific subduction developed (Wu et al., 2011). These two continental arc systems provide an excellent natural laboratory for examining the processes leading to crustal growth along convergent continental margins.

\section{Tectonic Setting}

\subsection{The North China Block}

The North China block is a fragment of Archean-Paleoproterozoic crust that was a stable craton from ca. 1650 Ma until the initiation of subduction along its northern and southern margins. It consists broadly of two crustal blocks (Eastern and Western blocks, EB and WB, Fig. 1) sutured together across an orogenic belt, variably termed the Central Orogenic Belt (COB) (Kusky and Li, 2003), or Trans-North China Orogen (TNCO, Fig. 1) ( Zhao, 2001). The timing of assembly of North China across this orogenic belt is controversial, with some workers placing the collision along an earliest Paleoproterozoic COB at ca. 2.5 Ga (Kusky, 2011; Kusky and Li, 2003), and others placing it along a later Paleoproterozoic TNCO at ca. $1.85 \mathrm{Ga}$ (Zhao, 2001; Zhao, 2013). In any case, it is abundantly clear from detrital zircon work in North China that the Eastern Block is characterized by two major events, one at $\sim 2.5 \mathrm{Ga}$ and the other at $\sim 1.85 \mathrm{Ga}$ (Cope et al., 2005; Yang et al., 2006); the latter event may reflect collision across the TNCO (Zhao, 2001) or an event that affected the entire northern margin of the North China block (Kusky, 2011). The Eastern Block of North China is also known to contain an older nucleus: zircon U-Pb ages of up to $3.8 \mathrm{Ga}$ have been reported from metamorphosed trondhjemite and quartz diorite in the Anshan and East Hebei regions (Liu et al., 2008; Wan et al., 2009; Zhao, 2013) (A and EH, Fig. 1).

The period between $\sim 1650-450$ Ma lacks significant magmatic activity in northern North China, save for riftrelated diabase sills found in some Mesoproterozoic sedimentary sequences (Zhang et al., 2009b). During the billion-year period following widespread Mesoproterozoic magmatism, North China is considered to have been a stable craton (hence the widely used term "North China Craton" to refer to the block, despite the fact that it is no longer a craton, sensu stricto). Mesoproterozoic-Ordovician marine strata spanning this age range in North China 
are thought to represent a north-facing passive margin sequence (Meng et al., 2011), developed following Mesoproterozoic rifting of North China from the Columbia supercontinent (Zhang et al., 2009b; Zhao, 2013).

\subsection{The IMPU: active northern margin of North China}

A magmatic belt along the northern margin of the NCB initiated in Paleozoic time (Cope et al., 2005; Zhang et al., 2007), following Late Silurian-earliest Devonian accretion of the early Paleozoic Bainaimiao arc to the northfacing passive margin of North China (Shuanhong Zhang et al., 2014). The magmatic belt, termed the Inner Mongolia Paleo-uplift (IMPU) because it is characterized by Mesozoic strata overlying crystalline basement once regarded as Precambrian in age (Zhang et al., 2009a), was emplaced into the preexisting Paleoproterozoic and Archean crust of North China, and extends the full length of the continental margin (Xiao et al., 2003). Recent studies of Carboniferous-Permian plutons composing the IMPU along the northern margin of North China reveal that they are mainly hydrous, calc-alkaline or high-K calc-alkaline intrusives with negative $\varepsilon_{\mathrm{Nd}}(\mathrm{t})$ values, negative $\varepsilon_{\mathrm{Hf}}(\mathrm{t})$ values, and ${ }^{87} \mathrm{Sr}^{86}{ }^{8 \mathrm{Sr}_{\mathrm{i}}}$ of ca. 0.704-0.706 (Bai et al., 2012; Zhang et al., 2009a; 2007), indicating that they were emplaced in an Andean-style volcanic arc.

There is broad agreement that the Paleo-Asian Ocean, which once separated North China from Altaid arc terranes that now occupy Mongolia and northern North China, closed in Late Permian-Early Triassic time via synchronous south-directed subduction beneath North China and north-directed subduction beneath one or more Altaid arcs, ultimately producing the Solonker suture (Eizenhöfer et al., 2014; Xiao et al., 2003). Collision deformed a wide zone along the northern margin of North China, forming a dominantly south-vergent fold-thrust belt (Shihong Zhang et al., 2014). ${ }^{40} \mathrm{Ar} /{ }^{39} \mathrm{Ar}$ cooling histories and aluminum-in-hornblende barometry of IMPU plutons indicate that the IMPU arc was uplifted gradually from depths of $>18 \mathrm{~km}$ during Carboniferous-Permian time, and then much more rapidly during collision in Late Permian-Early Triassic time (Zhang and Y. Zhao, 2013).

Sedimentation on the North China block south of the IMPU arc commenced in Carboniferous time, and is underlain by an enigmatic, craton-wide disconformity beneath which all Devonian-Silurian strata are missing (HBGMR, 1989; Wang et al., 2010) (Fig. 2). The overlying section of Carboniferous-Triassic strata consists of a succession of Permo-Triassic fluvial redbeds that overlie quartz-rich, variably coal-bearing Carboniferous clastic 
rocks. The redbed sequence coarsens upwards to a laterally extensive pebble-boulder conglomerate of well-

102 rounded quartzite, carbonate, volcanic, and crystalline clasts that is hundreds of meters thick (Fig. 2). The

103 consistency of this succession of rocks across widely scattered exposures suggests that they were deposited in a

104 single, large-scale basin that was destroyed by subsequent tectonism (Liu et al., 2007). The entire Carboniferous-

105 Triassic clastic succession is unconformably overlain by Lower-Middle Jurassic coal-bearing sandstone,

106 conglomerate, and lacustrine shale that are locally preserved both above the Triassic conglomerate and with

107 angular unconformity above deformed older strata. In one location (near Lingyuan, LY, Fig. 1), a section of

108 Upper Triassic conglomerate, sandstone, and shale (the Dengzhangzi Formation) occurs above a ca. 240-220 Ma

109 volcanic succession (the Shuiquangou Formation) that unconformably overlies Ordovician carbonate rocks (Davis

110 et al., 2009). Collectively, these late Paleozoic-Mesozoic strata in the Yanshan belt preserve an exquisite detrital

111 zircon record of arc magmatism and subsequent arc-continent collision that is the subject of this paper.

\section{3. Detrital Zircon $\mathrm{U} / \mathrm{Pb}$ and $\boldsymbol{\varepsilon}_{\mathrm{Hf}}(\mathrm{t})$ results}

113 Detrital zircon analyses were performed at the Arizona LaserChron Center (ALC) at the University of Arizona,

114 Tucson, using standard methods and analytical equipment outlined in Appendix A. The locations of individual

115 samples, the instruments used for each sample, and their detrital zircon age determinations and Lu/Hf isotope

116 ratios are provided in Appendix B. An R script written by the author that was used to process and graphically

117 display the data is provided in Appendix C.

118 Carboniferous-Middle Jurassic sandstones were selected from four regions of the Yanshan belt where relatively

119 continuous stratigraphic sections are preserved (Fig. 1). Detrital zircons from these sandstones are merged into

120 two lithostratigraphic intervals for comparison (Fig. 2): 1) Carboniferous-Triassic strata below the Triassic

121 conglomerate; and 2) Triassic-Middle Jurassic strata within and overlying the conglomerate. The Triassic

122 conglomerate constitutes the lowermost occurrence of Phanerozoic conglomerate in North China, and therefore

123 represents the oldest significant phase of Mesozoic tectonism in the Yanshan belt. This tectonism is most likely

124 due to the collision between North China and the Altaid arc terranes of Mongolia following closure of the Paleo-

125 Asian ocean. Previous studies have documented that the Lower-Middle Jurassic coal measures overlying this

126 conglomerate contain abundant zircons bearing positive $\varepsilon_{\mathrm{Hf}}(\mathrm{t})$ signatures, interpreted by those authors to indicate a 
provenance shift from North China to North China + Altaid sources following the accretion of Altaid oceanic arc terranes to North China along the Solonker suture (Meng et al., 2010; Yang et al., 2006), which suggests that the conglomerate is indeed a product of collision between those two blocks. Although the conglomerate is most certainly diachronous, its use as a stratigraphic marker provides a convenient means of subdividing the strata by provenance for the purposes of this paper without the need to establish a rigorous chronostratigraphic framework.

Sandstones above and below the conglomerate contain prominent detrital zircon (DZ) age populations centered at $\sim 2500, \sim 1850$, and $\sim 1730 \mathrm{Ma}$ (Figs. 3A and C). All three of these groups constitute a typical Eastern Block DZ signature, the $\varepsilon_{\mathrm{Hf}}(\mathrm{t})$ signatures of which indicate that a mantle extraction event occurred at $2.5 \mathrm{Ga}$, followed by reworking of the $2.5 \mathrm{Ga}$ crust during the later two events. The $2.5 \mathrm{Ga}$ mantle extraction event, as indicated by the coincidence of $\varepsilon_{\mathrm{Hf}}(\mathrm{t})$ zircon values and depleted mantle (DM) at this time (Fig. 3), also involved reworking of older crust. This older crust was probably the older continental nucleus preserved in the Anshan and North Hebei Regions (A and EH, Fig. 1), whose $\varepsilon_{\mathrm{Hf}}(\mathrm{t})$ values also coincide with $\mathrm{DM}(\mathrm{t})$. As is typical in North China, few zircons are present with ages between $\sim 1650$ and $\sim 450 \mathrm{Ma}$, during which time the North China Block was a stable craton (Fig. 3A).

The DZ ages shown in Fig. 3B (100-500 Ma DZ ages below the Triassic conglomerate) cluster into three welldefined groups with peaks at ca. 380, 320, and 260 Ma, broadly similar to age clusters for the IMPU arc identified by prior DZ studies at Baotou (B, Fig. 1) along the northern margin of North China $1000 \mathrm{~km}$ to the west (Cope et al., 2005), and in northern Ordos (Li et al., 2010; Li and Huang, 2013). Each peak represents a mixture of several primary age sources, as evidenced by their trough-to-trough MSWDs of 2.59, 3.96, and 5.59, respectively (an MSWD of unity would represent a single source age). Together, they define an arc tempo for the IMPU arc with a period between flare-ups of approximately 60 m.y., similar in frequency to the tempo of Cordilleran continental arc magmatism (DeCelles et al., 2009; Paterson and Ducea, 2015). The $\varepsilon_{\mathrm{Hf}}(\mathrm{t})$ values of zircons within these peaks lie within a well-defined range, superimposed on Fig. 3D for comparison and discussed in detail in the following 151 within North China (see below). 
152 Sandstone samples drawn from within and above the Triassic conglomerate (Fig. 3C-D) contain several

153 populations of both $\mathrm{DZ}$ ages and $\varepsilon_{\mathrm{Hf}}(\mathrm{t})$ values that fall out of the main range of values present in Fig. 3A-B, 154 signifying the uplift of on-craton and off-craton sources outside the IMPU arc following closure of the Paleo155 Asian ocean. The first of these is a population of detrital zircons whose ages overlap with the continental arc ages 156 in Fig. 3A-B, but whose $\varepsilon_{\mathrm{Hf}}(\mathrm{t})$ values are strongly negative (-30 to -55$)$. These zircons must be derived from the 157 older (Eoarchean to Paleoarchean) North China continental nucleus exposed at Anshan and East Hebei (A and 158 EH, Fig. 1; green data points and field, Figs. 3 A and C), reworked by inboard Paleozoic IMPU arc magmatism. 159 The second population consists of grains with modestly negative $\varepsilon_{\mathrm{Hf}}(\mathrm{t})$ values that predate ca. $410 \mathrm{Ma}$ initiation of 160 the continental arc along the northern margin of North China. Most of these have ages and $\varepsilon_{\mathrm{Hf}}(\mathrm{t})$ values consistent 161 with derivation from the Bainaimiao Arc (BNM Arc, Fig. 1B; cf. Shuanhong Zhang et al., 2014), although a 162 single 450 Ma grain has strongly negative $\varepsilon_{\mathrm{Hf}}(\mathrm{t})$ and therefore probably represents a 450 Ma reworking event of 163 unknown origin in the Anshan block. A third population consists of concordant grains with ages from 1650-350 164 Ma and positive to weakly negative $\varepsilon_{\mathrm{Hf}}(\mathrm{t})$ values that are distinct from other populations. These are certainly not 165 166 167 168 169 derived from the North China block, because their $\varepsilon_{\mathrm{Hf}}(\mathrm{t})$ values are too high and the NCB lacks significant magmatism during this period. These match well with primary DZ ages and $\varepsilon_{\mathrm{Hf}}(\mathrm{t})$ values obtained from accreted terranes within the Altaids (Eizenhöfer et al., 2015). A final population consists of grains younger than $\sim 420 \mathrm{Ma}$ with positive $\varepsilon_{\mathrm{Hf}}(\mathrm{t})$ values that are distinct from those in North China or the IMPU arc. These must be sourced from reworked juvenile crust of the Altaids.

Two younger age peaks occur in Fig 3C-D at 230 and 174 Ma. A third magmatic flare-up, well-documented in North China (Wu et al., 2005), occurs at ca. 126 Ma. Collectively, these disrupt the $\sim 60$ m.y. periodicity of magmatism that characterizes IMPU continental arc magmatism prior to that time, and establish a new periodicity of ca. 50 m.y. that is temporally out-of-phase with that of the IMPU. U-Pb age spectra compiled from in situ studies of granitoids in northeast China (Wu et al., 2011) nicely demonstrate this periodicity (red line, Fig. 3D). Each of the peaks younger than the 260 Ma collision between North China and the Altaids contains zircons with both positive and negative $\varepsilon_{\mathrm{Hf}}(\mathrm{t})$ values, therefore whatever magmatism was taking place at that time must have spatially overlapped both the juvenile crust of the Altaids and the ancient crust of North China. The most strongly differentiated values occur in the $174 \mathrm{Ma}$ peak, whereas positive and negative $\varepsilon_{\mathrm{Hf}}(\mathrm{t})$ values overlap somewhat in 
the 230 Ma peak. The trends of Mesozoic continental-margin magmatic activity in east Asia (red lines, Fig. 1A)

180 overlap both North China and the Altaids, thus the periodicity and $\varepsilon_{\mathrm{Hf}}(\mathrm{t})$ signatures of these younger grain

181 populations strongly suggest reworking of juvenile Altaid crust and evolved North China crust during arc

182 magmatism related to Paleo-Pacific subduction, following closure of the Paleoasian Ocean.

\section{Arc tempo in the IMPU}

Three distinct, overlapping temporal trends occur in $\varepsilon_{\mathrm{Hf}}(\mathrm{t})$ data from the IMPU arc (Fig. 4), and these are strongly correlated to the relative abundances of detrital zircons over time. The first is an overall increase in $\varepsilon_{\mathrm{Hf}}(\mathrm{t})$ values over the entire 170 m.y. lifespan of the arc (trend E in Fig. 4). The second constitutes a series of three short-term ( $<60$ m.y.) negative excursions, which occur over the timespan of each flare-up in the arc and indicate significant additions of crustal component to arc magmatism over the 60 m.y. timescale of each flare-up (trends A-C in Fig.

4). Each negative excursion is separated from the next by positive excursions (D, Fig. 4), which span the magmatic lulls between flare-ups. Each subsequent flare-up begins and ends with more elevated $\varepsilon_{\mathrm{Hf}}(\mathrm{t})$ values than the last. Similar trends do not appear in the $\varepsilon_{\mathrm{Hf}}(\mathrm{t})$ values for zircons from more inboard magmatic settings, as illustrated by the absence of such trends in the strongly negative $\varepsilon_{\mathrm{Hf}}(\mathrm{t})$ values of zircons derived from the off-axis Anshan region (Fig. 4).

A nearly identical relationship between arc tempo and $\varepsilon_{\mathrm{Nd}}(\mathrm{t})$ values of arc magmatism exists in the Cordilleran arcs, where an elegant model for their genesis has been proposed and linked to observed tectonic histories (DeCelles et al., 2009). In this model, arc magmatism initiates by asthenospheric melting and the mafic, hightemperature melts thus produced interact with continental crust to produce a hybrid mantle-crustal melt with $\varepsilon_{\mathrm{Nd}}(\mathrm{t})$ values that are elevated from those of the crustal arc substrate. Subsequent "feed-in" of melt-fertile continental crust by retroarc underthrusting increases the continental crustal component of the melts, producing increasingly voluminous melts with increasingly lower $\varepsilon_{\mathrm{Nd}}(\mathrm{t})$ values over time. The residuum (or cumulate) of this partial melting accumulates as a negatively buoyant, refractory "root" at the base of the crust, which eventually attains

202 critical mass and founders into the mantle (e.g., Ducea, 2002). The missing root volume is replaced by asthenospheric melts with elevated $\varepsilon_{\mathrm{Nd}}(\mathrm{t})$ values, and the temporary loss of thick, melt-fertile lithosphere beneath 
depleted mantle melts to the lower crust during root removal elevates the baseline $\varepsilon_{\mathrm{Hf}}(\mathrm{t})$ signature of the arc substrate, and so each subsequent flare-up has a higher initial $\varepsilon_{\mathrm{Hf}}(\mathrm{t})$ signature relative to the last.

The decreasing $\varepsilon_{\mathrm{Hf}}(\mathrm{t})$ values that occur during each successive peak in the DZ spectra thus represent orogenic trends that require ongoing crustal shortening in order to develop. This interpretation is broadly consistent with geological evidence for crustal shortening within and inboard of the IMPU arc system beginning prior to

210 Carboniferous time and lasting through the Triassic. The North China block is characterized by a complete lack of 211 Silurian-Devonian strata, indicating that the crust of North China remained highstanding during the early phases 212 of IMPU arc development. The generation of subsidence sufficient to accommodate the continental strata that are 213 the subject of this paper did not begin until Carboniferous time, which may signify the onset of flexural 214 subsidence related to ongoing uplift in the IMPU. Carboniferous-Triassic strata (in red, Fig. 1B) are completely 215 missing north of a line bounding the southern margin of the IMPU (barbed line, Fig. 1B). In the IMPU, Middle 216 Jurassic strata unconformably overlie arc plutons and crystalline basement of the TNCO and Eastern Block, 217 indicating substantial pre-Jurassic uplift. At Nanpiao in Liaoning Province (NP, Fig. 1B), Carboniferous strata 218 unconformably overlie a series of beveled detachment folds developed in lower Paleozoic carbonates (Jiasui, 219 2014); in the Daqing Shan at Baotou, Inner Mongolia (B, Fig. 1B), the coal measures overlie Ordovician carbonates along a modest angular unconformity (Darby et al., 2001).

221 The intervening positive excursions (D, Fig. 4) occur during the magmatic lulls between each flare-up. These cannot be simply related to regional continental extension, because Phanerozoic zircons with strongly negative $\varepsilon_{\mathrm{Hf}}(\mathrm{t})$ values that must be derived from the more inboard Anshan region ("Anshan Segment", Fig. 4) record only a secular negative trend with no positive excursions. Hence, whatever process is generating the positive trends is restricted to the arc itself. Given the increasing degree of crustal melting that precedes them, the crustal thickening required to generate melts with progressively more $\varepsilon_{\mathrm{Hf}}(\mathrm{t})$-negative signatures, and their arc-axis localization, it is most likely that lithosphere removal (delamination) is the cause of these positive trends.

Figure 5 shows a model for the tectonic development of the IMPU arc, along with a predicted $\varepsilon_{\mathrm{Hf}}(\mathrm{t})$ response for each time interval. The passive margin along the northern NCB was first disrupted by Late Silurian-Early 230 Devonian collision with the exotic Bainaimiao arc (Shuanhong Zhang et al., 2014). Continued plate convergence 
231 following arc accretion would have required subduction to step northward and flip polarity, initiating south-

232 directed subduction along the northern margin of the NCB. Subduction initiation would also have removed 233 compressional stress on the collisional orogen, allowing it to collapse. A belt of Early-Middle Devonian (ca. 380 -

$234400 \mathrm{Ma}$ ) alkaline magmatism occurs along the northern margin of the NCB, which has been attributed to post235 collisional extension (Huang and Hou, 2017; Zhang et al., 2007; Zhang et al., 2010). However, some mafic 236 plutons of this age along the North China margin are hydrous, indicating subduction affinity (Teng et al., 2015).

237 Many of the Devonian alkaline intrusive bodies also appear to be hydrous: they contain abundant hornblende, and 238 K-feldspar and plagioclase occur as separate phases (c.f. Huang and Hou, 2017; Zhang et al., 2007). The North 239 China cratonic lithosphere was as thick as $180 \mathrm{~km}$ in Ordovician time, as indicated by mantle xenoliths in North 240 China kimberlites of that age (Menzies et al., 2007). It seems reasonable to infer that low-degree flux melting of 241 the refractory North China SCLM at the onset of subduction (prior to establishment of a mantle wedge thermal 242 regime) could be a factor in the petrogenesis of the Devonian alkaline magmas; additional magmas may have 243 been generated by decompression melting of North China SCLM or lower crust during post-orogenic extension 244 following collision of the Bainaimiao arc (Fig. 5). Thus, the IMPU arc likely initiated in a post-orogenic setting in 245 Early Devonian time, following a reversal in subduction polarity due to arc-continent collision.

246 By $380 \mathrm{Ma}$, arc magmatism and renewed crustal shortening had begun to increasingly rework continental crust. 247 The oldest peak in the DZ spectra (at $380 \mathrm{Ma}$ ) occurs in a distribution that is skewed young, and the younger tail 248 of this age distribution contains a clear decreasing trend in clustered $\varepsilon_{\mathrm{Hf}}(\mathrm{t})$ values that begins at about $400 \mathrm{Ma}$ and 249 is more strongly negative than the similar trends of successive peaks (Fig. 4). The North China SCLM is thought 250 to have been enriched, with an $\varepsilon_{\mathrm{Hf}}(\mathrm{t})$ value of -6 at $480 \mathrm{Ma}$ and decreasing thereafter (Li et al., 2011; Fig. 3). 251 Interaction of $\varepsilon_{\mathrm{Hf}}(\mathrm{t})$-negative SCLM melts with partial melts of North China continental crust could explain the 252 anomalously low $\varepsilon_{\mathrm{Hf}}(\mathrm{t})$ signatures that characterize the 380 Ma peak relative to successive flare-ups, which is a 253 characteristic not obvious in Cordilleran examples (cf. DeCelles et al., 2009). The enriched North China SCLM 254 must have been removed from beneath the IMPU arc prior to $350 \mathrm{Ma}$, because $\varepsilon_{\mathrm{Hf}}(\mathrm{t})$ values from IMPU arc 255 zircons at that time exceed those of SCLM, requiring the involvement of depleted mantle (Fig. 3). 
In epsilon space, the slopes of the orogenic trends in the three pulses of magmatism from North China increase with each subsequent pulse (Fig. 4), which may indicate greater rates of "feed-in" of underthrusted continental crust beneath the arc during development of a retroarc wedge (Fig. 5), or may partially be an artifact of mixing of crustal melts with different mantle melt sources at different times (e.g., DM, SCLM). The former notion is supported by thermobarometry of Devonian-Permian plutons in the IMPU, which suggests that rates of uplift 261 increased throughout this period, culminating in the Permian (Zhang et al., 2007; Zhang and Zhao, 2013). The 262 steepest orogenic trend occurs in association with the final pulse of magmatism centered at $259 \mathrm{Ma}$, and the oldest 263 major cluster of positive $\varepsilon_{\mathrm{Hf}}(\mathrm{t})$ values are this age as well. This magmatic peak coincides with the timing of 264 collision between North China and the Altaid arc terrane(s) of Mongolia (Eizenhöfer et al., 2014), which would 265 have induced rapid crustal thickening. It is generally accepted that this collision occurred following bi-vergent 266 subduction beneath both colliding blocks (Eizenhöfer et al., 2014; Xiao et al., 2003). The broad spread of $\varepsilon_{\mathrm{Hf}}(\mathrm{t})$ 267 values that characterize this final burst of magmatism probably are caused by syn- and post-collisional foundering 268 of the subducted slab beneath the evolving collision zone, and the subsequent interaction of melts thus produced 269 with a rapidly thickening collisional orogenic wedge that incorporated both the juvenile crust of the Altaid oceanic arcs and the ancient continental crust of North China (Fig. 5).

\section{Mesozoic magmatism and initiation of the Paleo-Pacific plate margin}

Two well-documented magmatic flare-ups occurred in the eastern NCB during Mesozoic time, following closure of the Paleoasian Ocean (Fig. 3D). These occur with peaks at ca. $175 \mathrm{Ma}$ and $125 \mathrm{Ma}$ (Wu et al., 2011), and are extensively preserved in eastern North China as thick accumulations of largely andesitic volcanic strata (Fig. 2). A third peak, strongly indicated by our detrital zircon data (but not by the data of Wu et al., 2011) occurs at 228 Ma. Collectively, these three Mesozoic age peaks define a regular magmatic periodicity of $\sim 50$ m.y. that is temporally out-of-phase with the magmatism in the IMPU and may constitute a second arc tempo related to Paleo-Pacific subduction. This is an intriguing possibility that remains to be investigated. Ma) alkaline intrusive rocks are widely distributed throughout the NCB (Xu et al., 2013; Yang et al., 2012b; Ye et al., 2014), suggesting continental extension following closure of the Paleo-Asian Ocean (Zhang et al., 2012), 224- 
218 Ma plutons in eastern North China, closer to the Paleo-Pacific margin, are hydrous and calc-alkaline (Yang et al., 2012a). The inboard alkaline magmatism may be linked to continental extension during initiation of PaleoPacific subduction, in much the same way that Early-Middle Devonian alkaline magmatism preceded the IMPUby generating a free surface into which previously overthickened orogenic crust could extrude. Both the Jurassic (175 Ma) and Cretaceous (125 Ma) peaks correlate to episodes of voluminous calc-alkaline (or high-K calcalkaline) magmatism throughout the eastern NCB (Davis, 2003; Ma et al., 2016). Jurassic-Cretaceous magmatism in east Asia occurs along a trend that parallels the east Asian continental margin, spanning several blocks that amalgamated in Permo-Triassic time along roughly E-W trending suture zones (Fig. 1A). The margin-parallel magmatic trend roughly parallels a well-documented gravity lineament that divides present-day North China into a stable western block and a deformed eastern block, the latter characterized by anomalously thin lithosphere (Griffin et al., 1998). Most workers agree that lithospheric thinning in eastern North China occurred during Mesozoic time. Although some disagreement exists as to the mechanisms and exact timing of lithosphere loss in eastern Asia, the spatial and temporal correlation of magmatism and lithospheric thinning suggests a causal link between the two.

Studies in North China have documented episodic lithosphere loss at times that are predicted by the tempo of Jurassic-Cretaceous magmatism. For example, the 159-144 Ma Xinglonggou volcanics near Chaoyang (CY, Fig 1B) are thought to represent an episode of lithospheric thinning in the NCB (Gao et al., 2004), and correspond in age to onset of the magmatic lull between the 174 and $125 \mathrm{Ma}$ U-Pb age peaks in Fig. 3D. Basalts of Early Cretaceous age (>110 Ma) in North China correspond to the 125 Ma magmatic peak in Fig. 3D, and have negative $\varepsilon_{\mathrm{Nd}}(\mathrm{t})$, negative $\varepsilon_{\mathrm{Hf}}(\mathrm{t})$, and high ${ }^{87} \mathrm{Sr}^{86} \mathrm{Sr}_{\mathrm{i}}$ consistent with partial derivation from melting of North China continental crust. North China basalts younger than $110 \mathrm{Ma}$, corresponding to onset of the magmatic lull following the 125 Ma peak, have positive $\varepsilon_{\mathrm{Nd}}(\mathrm{t})$, positive $\varepsilon_{\mathrm{Hf}}(\mathrm{t})$, and low ${ }^{87} \mathrm{Sr} /{ }^{86} \mathrm{Sr}_{\mathrm{i}}$, isotopic characteristics that fall within the mantle array and indicate wholesale loss of the eastern North China lithosphere by that time (Meng et al., 2015). These observations are consistent with the generation of dominantly crustal melts during flare-ups, 307 lulls. 
Root loss beneath a continental arc should increase the surface elevation and freeboard of the arc, inducing crustal

extension. Several episodes of extension in the eastern block took place during the Mesozoic, a span of time that

310 was otherwise dominated by crustal shortening (Davis et al., 2001). Volcanic strata of the Yanshan belt that

311 correspond to each of the three peaks in Fig. 3D are notable in that they each overlie significant angular

312 unconformities (Fig. 2), signifying a change in tectonic setting. The Upper Triassic-Lower Jurassic Dengzhangzi

313 Formation overlies volcanic strata that correspond in age to the 228 Ma peak, and was deposited in an extensional

314 lacustrine basin following an episode of thrust faulting (Davis et al., 2009). The Sonid Zuoqi metamorphic core

315 complex (SZ, Fig. 1B) developed at ca. 208 Ma, about the same time as Dengzhangzi extension (Davis et al.,

316 2004). The existence of a weak Middle-Late Jurassic extensional event, corresponding to the lull between the 175

317 Ma and 125 Ma peaks, has been recognized for some time (Davis et al., 2001). Mid-Cretaceous volcanism

318 corresponding to the 125 Ma peak was followed by the development of numerous rift basins parallel to the

319 continental margin (Cope and Graham, 2007; Davis et al., 2001), alkaline magmatism (Yang et al., 2007), and

320 metamorphic core complex development (Davis et al., 2001). The mid-Cretaceous extensional events are

321 associated with volcanism widely considered to be syn-extensional. However, the most voluminous volcanism

322 occurring in association with many of these basins lies below their sedimentary fill, and does not appear to

323 thicken appreciably towards fault-bounded margins, as the sedimentary fill overlying them does (Cope and

324 Graham, 2007). In each of these cases, extensional structures and basins appear to post-date the magmatic flare-

325 ups documented by peaks in the zircon age spectra of Fig. 3D, with extension taking place during the intervening

326 magmatic lulls represented by overlying syn-rift strata.

\section{Implications for continental arc magmatism in North China and beyond}

328 The evolved isotopic character of North China, relative to the juvenile character of the Phanerozoic mantle, makes

329 it an ideal natural laboratory in which to characterize the relative contributions of mantle and crustal melting to

330 arc magmatism. The magmatic history of eastern North China presented above is consistent with the view that

331 late Paleozoic-Mesozoic magmatism in North China originated largely in two different volcanic arc systems that

332 experienced periodic magmatism associated with upper plate thickening/foundering cycles. Although this remains

333 to be tested for Mesozoic magmatism, the relationships between isotopic excursions and flare-ups recorded for the

334 IMPU arc provides a temporal framework for crustal shortening and extension that should be further tested by 
field, geochronological, geochemical, and geophysical studies. The relationships between flare-ups and documented extension/lithosphere loss in North China during the Mesozoic suggests that a complimentary Hfisotopic story may remain to be documented for the Paleo-Pacific system, and that the Mesozoic lithosphere loss in the Eastern Block of North China took place during at least three separate events that may have been driven by foundering of the residues of paleo-Pacific arc magmatism beneath thickened continental crust (cf. Yang et al., 340 2010).

341 Although the thickening/foundering model applied here requires no external forcing (Paterson and Ducea, 2015), 342 regional tectonic events almost certainly played a role in the development of the magmatic cyclicity documented 343 in this paper-particularly in the Mesozoic, when intracontinental deformation took place throughout North China 344 (Davis et al., 2001). For example, the Mongol-Okhotsk seaway closed in Late Jurassic-Early Cretaceous time 345 (Van der Voo et al., 2015), and widespread intracontinental shortening associated with that event affected North China (Davis et al., 2001). Middle-Late Triassic collision between North China and South China (Liu et al., 2015) 347 affected it as well. The structural complexity of the Eastern Block, much of which demonstrably developed in the 348 Mesozoic, attests to widespread intracontinental deformation during that time (Davis et al., 2001), with interfering 349 structural trends of many different directions (Deng and Koyi, 2015; Li et al., 2016; Zhang et al., 2004). The 350 history of terrane accretion along the Paleo-Pacific convergent margin may have been quite complicated (Yang, 351 2013), and may have affected continental shortening rates along that margin throughout the Mesozoic.

352 Intracontinental crustal thickening and plateau growth associated with these events may be partly responsible for 353 the anomalously wide zone of magmatism and lithosphere loss that affected North China in the Mesozoic, which 354 was then further widened by subsequent Mesozoic-Cenozoic extension.

355 Regardless of whether the drivers of magmatic cyclicity were external or internal to the continental magmatic 356 systems of North China, one major prediction of this study is that lithosphere loss and crustal extension in 357 magmatic arcs (as documented by elevated $\varepsilon_{\mathrm{Hf}}(\mathrm{t})$ ) is likely to be associated with periods of relative magmatic 358 quiescence following igneous flare-ups, and not during the flare-ups, as is commonly assumed (cf. Wu et al., 359 2005). Instead, it is possible that much of the voluminous magmatism in North China was associated with crustal 360 melting during shortening, and not extension. These possibilities, along with the temporal framework from the 361 magmatic tempos presented in this study, should be considered in future tectonic studies in North China. 
362 The data presented here demonstrate the utility of large- $\mathrm{N} \mathrm{U} / \mathrm{Pb}$ and $\mathrm{Lu} / \mathrm{Hf}$ studies of detrital zircons in tracking

363 melt sources through time within continental arc systems. The isotopic record of IMPU magmatism may be

364 archetypical of the relationship between isotopic excursions and flare-ups in continental arcs where upper plate

365 thickening/foundering cycles drive continental arc tempos. This archetypical relationship may potentially provide

366 a means by which to distinguish contractile continental arc magmatism from other sources of magmatism (e.g.,

367 oceanic arcs, extensional continental arcs, rifts, hotspot plumes, etc.). Such a relationship remains to be

368 investigated in the Mesozoic paleo-Pacific magmatic systems of North China.

\section{Acknowledgements}

371 This research was funded by NSF-EAR 1145230 to the author and NSF-EAR 1338583 to Arizona LaserChron

372 Center (ALC). Additional funding provided by a DePauw University Faculty Fellowship and the DePauw

373 Professional Development Fund. Comments and references from three anonymous reviewers and editor An Yin 374 vastly improved this manuscript from its initial submission. Conversations with Professor James Mills (DePauw 375 University) helped to guide my interpretation of these comments and references. Special thanks to Mark Pecha 376 and the staff at ALC for their guidance and assistance with sample analysis, particularly for their help with our 377 Lu/Hf analyses. DePauw University undergraduates Nick Williams, Steve Dobbs, Alexa Masters, Forrest Kunkel, 378 Will Joseph, Yihao Xu, and Martha Parsons participated in fieldwork, sample collection, and sample analysis. 379 Professor Zhang Changhou and graduate students Li Chengming, Zhang Yipeng, Gao Jianweng, Ouyang Jiasui, 380 and Yi Lin at China University of Geosciences provided valuable field assistance, collaboration, support, and 381 friendship. Our drivers and good friends Zhang Yong and Zhang Wei kept us all safe on the roads. 


\section{Figure captions}

384 Figure 1. Geotectonic maps of the North China block and environs. Left panel (A) shows major tectonic 385 provinces and boundaries of east Asia; North China shown in gray. Eastern Block (EB), Western Block (WB), 386 and Trans-North China Orogen (TNCO) shown as shades of gray within North China; boundaries from (Zhao, 387 2013). QDS= Qinling-Dabie suture; $\mathrm{O}=$ Ordos stable block; $\mathrm{S}=$ Songliao Basin. Red lines denote (1) western limit 388 of Late Triassic-Middle Jurassic volcanism, and (2) western limit of Late Jurassic-Early Cretaceous volcanism, 389 from (Wu et al., 2011) and (Zhou et al., 2006). Dark gray area south of Solonker Suture represents the accretionary complex along the northern margin of North China, shown in more detail in right panel. Right panel (B) is detail of area shown by rectangle in left panel, using same color scheme to denote tectonic elements. Additional tectonic elements shown are $\mathrm{SSZ}=$ Solonker Suture Zone; OSAB= Ondor Sum Accretionary Belt; BNM= Bainaimiao Arc. IMPU arc denoted by random "V" pattern. Dashed line north of the arc denotes approximate northern limit of Archean continental crust of North China (compiled from Shuanhong Zhang et al., 2014 and Zhao, 2013), and barbed line to its south symbolizes the approximate location of major thrust fault system bounding its southern margin (Shuanhong Zhang et al., 2014). Areas discussed in text are: A= Anshan; B= Baotou; EH= East Hebei; NP= Nanpiao; NW= Ningwu; SZ = Sonid Zuoqi; WH=Western Hills. Sampling locations for this study are: $\mathrm{CH}=$ Chengde (Xiabancheng); $\mathrm{CY}=$ Chaoyang; $\mathrm{LY}=$ Lingyuan; $\mathrm{PQ}=$ Pingquan.

Figure 2. Generalized stratigraphy of the Yanshan region, Eastern Block of North China, showing stratigraphic intervals sampled and compiled in the DZ plots of Fig. 3. "Tcong" is Triassic conglomerate used as a lithostratigraphic marker to subdivide the strata shown in Fig. 3(A-B) from those in Fig. 3(C-D) by provenance. Unconformities are all strongly angular in nature, save for the disconformity at the base of the late Paleozoic section. Detailed information regarding sample location and stratigraphic position are provided in the Appendix.

Figure 3. $\mathrm{U} / \mathrm{Pb}$ Age spectra and $\varepsilon_{\mathrm{Hf}}(\mathrm{t})$ plots for zircons from upper Paleozoic-Mesozoic strata in the Yanshan foldthrust belt. Age probability spectra in all panels include both discordant (light gray) and concordant (dark gray) analyses. Concordance is defined as those analyses that intersect concordia at $2 \sigma$ uncertainty. Only $7.6 \%$ of the ages $>1000$ Ma exceed $10 \%$ discordance, and fewer than $0.5 \%$ exceed $20 \%$ discordance. Top panel shows $0-4.5$ 
Ga ages and $\mathrm{e}_{\mathrm{Hf}}(\mathrm{t})$ values for sandstone samples collected A) below and B) within/above Triassic conglomerate

411 ("Tcong" in Fig. 2). Green $\varepsilon_{\mathrm{Hf}}(\mathrm{t})$ values are in situ analyses of zircons from migmatite, schist, and trondhjemitic

412 gneiss of the Anshan region from (Wang et al., 2015). Bottom panel shows 100-500 Ma subsets of detrital zircons

413 from sandstone samples C) below and D) within/above Triassic conglomerate, overlain by in situ U-Pb age data

414 from granitoids of North China (Wu et al., 2011) shown in red. Error bars on $\varepsilon_{\mathrm{Hf}}(\mathrm{t})$ values are $1 \sigma$; error bars on 415 ages are $1 \sigma$ propagated along trajectories determined from measured ${ }^{176} \mathrm{Lu} /{ }^{177} \mathrm{Hf}$ ratio of each individual zircon 416 grain. Panel C) shows relative probability "heat map" $\left(\mathrm{P}_{\text {age }} \times \mathrm{P}_{\varepsilon \mathrm{Hf}(\mathrm{t})}\right)$, with red color indicating higher probability 417 and yellow indicating lower; heat map from C) included in D) for comparison to indicate range of ages and $\varepsilon_{\mathrm{Hf}}(\mathrm{t})$ 418 values consistent with derivation from the IMPU arc. Zircons with age and $\varepsilon_{\mathrm{Hf}}(\mathrm{t})$ that fall significantly outside this 419 range are likely derived from other sources. Interpreted source terranes for detrital age populations are shown at the bottom of each panel. Green and red vertically-ruled boxes are full range of expected $\varepsilon_{\mathrm{Hf}}(\mathrm{t})$ values for Anshan and Eastern Block (TNCO) continental crust, respectively, propagated through time along a bulk crustal ${ }^{176} \mathrm{Lu} /{ }^{177} \mathrm{Hf}$ ratio of 0.012 ; trajectory of propagation along a value of 0.015 is shown in top panel for reference. Note that use of this latter trajectory would cause the most $\varepsilon_{\mathrm{Hf}}(\mathrm{t})$-negative grains in panels $\mathrm{B}$ and $\mathrm{D}$ to have anomalously old model ages, and would also create overlap between Anshan and Eastern Block pure-melt fields. Gray vertically-ruled boxes in C) and D) indicate $\varepsilon_{\mathrm{Hf}}(\mathrm{t})$ values for North China enriched SCLM (Li et al., 2011).

Figure 4. $\mathrm{U} / \mathrm{Pb}$ Age spectra and $\varepsilon_{\mathrm{Hf}}(\mathrm{t})$ relative probability heat map $\left(\mathrm{P}_{\text {age }} \times \mathrm{P}_{\varepsilon \mathrm{Hf}(\mathrm{t})}\right)$ for all zircons (below and above conglomerate) derived from the IMPU arc (open circles, selected by $2 \sigma$ overlap with age and $\varepsilon_{\mathrm{Hf}}(\mathrm{t})$ of zircons sampled below the Triassic conglomerate). Also plotted are a linear model fit to mean ages and $\varepsilon_{\mathrm{Hf}}(\mathrm{t})$ of zircons from the IMPU arc (E; $N=308, R=.48, p<<.001)$, arrows highlighting negative excursions (orogenic trends) A, B and $\mathrm{C}$ through time (A and $\mathrm{B}$ are linear model fits, $\mathrm{C}$ is interpreted), and (D) intervening positive excursions (delamination trends). Provenance fields external to the IMPU arc are indicated along the margins.

Figure 5. Cartoons illustrating the tectonic development of the IMPU arc from Devonian time to closure of the Paleoasian Ocean, and the predicted $\varepsilon_{\mathrm{Hf}}(\mathrm{t})$ response to each event. "Peaks" refer to the Paleozoic age probability 
437 lithospheric mantle; $\mathrm{DM}=$ depleted mantle. Red hachured areas represent regions of melt generation; black 438 hachured areas indicate melt-depleted restite accumulations that later become negatively buoyant. 


\section{References Cited}

Bai, X., Liu, S., Wang, W., Yang, P., Li, Q., 2012. U-Pb geochronology and Lu-Hf isotopes of zircons from newly identified Permian-Early Triassic plutons in western Liaoning province along the northern margin of the North China Craton: constraints on petrogenesis and tectonic setting. International Journal of Earth Sciences 102, 671-685. doi:10.1007/s00531-012-0821-0

Cope, T. D., Ritts, B., Darby, B., Fildani, A., Graham, S. A., 2005. Late Paleozoic sedimentation on the northern margin of the North China block: implications for regional tectonics and climate change. International Geology Review 47, 270-296. doi: 10.2747/0020-6814.47.3.270

Cope, T. D., Graham, S. A., 2007. Upper crustal response to Mesozoic tectonism in western Liaoning, North China, and implications for lithospheric delamination. Geological Society, London, Special Publications 280, 201-222. doi:10.1144/SP280.10

Darby, B. J., Davis, G. A., Zheng, Y., 2001. Structural evolution of the southwestern Daqing Shan, Yinshan belt, Inner Mongolia, China. Geological Society of America Memoirs 194, 199-214. doi:10.1130/0-8137-11940.199

Davis, G. A., Meng, J., Cao, W., Du, X., 2009. Triassic and Jurassic tectonics in the eastern Yanshan Belt, North China: Insights from the controversial Dengzhangzi Formation and its neighboring units. Earth Science Frontiers 16, 69-86. doi: 10.1016/S1872-5791(08)60090-1

Davis, G. A., Xu, B., Zheng, Y. D., Zhang, W. J., 2004. Indosinian extension in the Solonker suture zone: The Sonid Zuoqi metamorphic core complex, Inner Mongolia, China. Earth Science Frontiers 11, 135-142.

Davis, G. A., 2003. The Yanshan belt of North China: tectonics, adakitic magmatism, and crustal evolution. Earth Science Frontiers 10, 373-384.

Davis, G. A., Zheng, Y., Wang, C., Darby, B. J., Zhang, C., Gehrels, G., 2001. Mesozoic tectonic evolution of the Yanshan fold and thrust belt, with emphasis on Hebei and Liaoning provinces, northern China. Geological Society of America Memoirs 194, 171-197. doi: 10.1130/0-8137-1194-0.171

DeCelles, P. G., Ducea, M. N., Kapp, P., Zandt, G., 2009. Cyclicity in Cordilleran orogenic systems. Nature Geoscience 2, 251-257. doi:10.1038/ngeo469

Deng, H., Koyi, H. A., 2015. Mega arrowhead interference patterns in the central part of the Yanshan Orogenic Belt, North China. Journal of Structural Geology 80, 25-37. doi:10.1016/j.jsg.2015.06.004

Ducea, M. N., 2002. Constraints on the bulk composition and root foundering rates of continental arcs: A California arc perspective. J. Geophys. Res. Solid Earth 107(B11), 2304. doi:10.1029/2001JB000643

Eizenhöfer, P. R., Zhao, G. C., Sun, M., Zhang, J., Han, Y., Hou, W., 2015. Geochronological and Hf isotopic variability of detrital zircons in Paleozoic strata across the accretionary collision zone between the North China craton and Mongolian arcs and tectonic implications. Geological Society of America Bulletin 127, 1422-1436. doi:10.1130/B31175.1

Eizenhöfer, P. R., Zhao, G. C., Zhang, J., Sun, M., 2014. Final closure of the Paleo-Asian Ocean along the Solonker Suture Zone: Constraints from geochronological and geochemical data of Permian volcanic and sedimentary rocks. Tectonics 33, 441-463. doi:10.1002/2013tc003357

Gao, S., Rudnick, R. L., Yuan, H. L., Liu, X. M., Liu, Y.S., Xu, W.L., Ling, W. L., Ayers, J., Wang, X. C., Wang, Q. H., 2004. Recycling lower continental crust in the North China craton. Nature 432, 892-897. doi:10.1038/nature03162

Garzione, C., Dettman, D., Quade, J., DeCelles, P., 2000. High times on the Tibetan Plateau: Paleoelevation of the Thakkhola graben, Nepal. Geology 28, 339-342. doi: 10.1130/0091-7613(2000) 28<339:HTOTTP> 2.0.CO;2

Garzione, C. N., Hoke, G. D., Libarkin, J. C., Withers, S., MacFadden, B., Eiler, J., Ghosh, P., Mulch, A., 2008. Rise of the Andes. Science 320, 1304-1307. doi:10.1126/science.1148615

Griffin, W. L., Zhang, A., O'Reilly, S., Ryan, C.G., 1998. Phanerozoic Evolution of the Lithosphere Beneath the Sino-Korean Craton, in: Flower, M.F.J., Chung, S., Lo, C., Lee, T. (Eds.), Mantle Dynamics and Plate Interactions in East Asia. pp. 107-126. doi: 10.1029/GD027p0107

HBGMR (Hebei Bureau of Geology and Mineral Resources), 1989. Regional Geology of Hebei Province, Beijing Municipality and Tianjin Municipality, Geological Memoir 15. Geological Publishing House, Beijing, China. (in Chinese).

Huang, D., Hou, Q., 2017. Devonian alkaline magmatism in the northern North China Craton: Geochemistry, SHRIMP zircon U-Pb geochronology and Sr-Nd-Hf isotopes. Geoscience Frontiers 8, 171-181. 
doi:10.1016/j.gsf.2016.02.006

Jiasui, O. Y., 2014. Characteristics and geochronology of the tectonic deformations in Huludao-Jianchang area, Western Liaoning province, and its significance. Master's thesis, China University of Geosciences, Beijing, 50 p. (In Chinese)

Kay, R., Mahlburg-Kay, S., 1993. Delamination and delamination magmatism. Tectonophysics 219, 177-189. doi:10.1016/0040-1951(93)90295-U

Kay, R. W., Mahlburg-Kay, S., 1991. Creation and destruction of lower continental crust. Geologische Rundschau 80, 259-278. doi:10.1007/BF01829365

Kusky, T. M., 2011. Geophysical and geological tests of tectonic models of the North China Craton. Gondwana Research 20, 26-35. doi:10.1016/j.gr.2011.01.004

Kusky, T. M., Li, J., 2003. Paleoproterozoic tectonic evolution of the North China Craton. Journal of Asian Earth Sciences 22, 383-397. doi:10.1016/S1367-9120(03)00071-3

Li, C., Zhang, C., Cope, T. D., Lin, Y., 2016. Out-of-sequence thrusting in polycyclic thrust belts: An example from the Mesozoic Yanshan belt, North China Craton. Tectonics 35, 2082-2116. doi:10.1002/2016TC004187

Li, H. Y., Bin He, Xu, Y. G., Huang, X. L., 2010. U-Pb and Hf isotope analyses of detrital zircons from Late Paleozoic sediments: Insights into interactions of the North China Craton with surrounding plates. Journal of Asian Earth Sciences 39, 335-346. doi:10.1016/j.jseaes.2010.05.002

Li, H. Y., Huang, X. L., 2013. Constraints on the paleogeographic evolution of the North China Craton during the Late Triassic-Jurassic. Journal of Asian Earth Sciences 70-71, 308-320. doi:10.1016/j.jseaes.2013.03.028

Li, Q. L., Wu, F. Y., Li, X. H., Qiu, Z. L., Liu, Y., Yang, Y. H., Tang, G. Q., 2011. Precisely dating Paleozoic kimberlites in the North China Craton and Hf isotopic constraints on the evolution of the subcontinental lithospheric mantle, Lithos 126, 127-134. doi:10.1016/j.lithos.2011.07.001

Liu, D., Wilde, S.A., Wan, Y., Wu, J., Zhou, H., Dong, C., Yin, X., 2008. New U-Pb and Hf isotopic data confirm Anshan as the oldest preserved segment of the North China Craton. American Journal of Science 308, 200231. doi:10.2475/03.2008.02

Liu, S., Qian, T., Li, W., Dou, G., Wu, P., 2015. Oblique closure of the northeastern Paleo-Tethys in central China. Tectonics 34, 413-434. doi:10.1002/2014TC003784

Liu, S., Zhang, J., Hong, S., Ritts, B., 2007. Early Mesozoic Basin Development and Its Response to Thrusting in the Yanshan Fold-and-Thrust Belt, China. International Geology Review 49, 1025-1049. doi:10.2747/00206814.49.11.1025

Ma, Q., Xu, Y. G., Zheng, J. P., Griffin, W. L., Hong, L. B., Ma, L., 2016. Coexisting Early Cretaceous High-Mg Andesites and Adakitic Rocks in the North China Craton: the Role of Water in Intraplate Magmatism and Cratonic Destruction. Journal of Petrology 57, 1279-1308. doi:10.1093/petrology/egw040

Meng, F., Gao, S., Niu, Y., Liu, Y., Wang, X., 2015. Mesozoic-Cenozoic mantle evolution beneath the North China Craton: A new perspective from Hf-Nd isotopes of basalts. Gondwana Research 27, 1574-1585. doi:10.1016/j.gr.2014.01.014

Meng, F., Gao, S., Yuan, H., Gong, H., 2010. Permian-Triassic (260-220 Ma) crustal growth of Eastern Central Asian orogenic belt as revealed by detrital zircon studies. American Journal of Science 310, 364-404. doi:10.2475/05.2010.02

Meng, Q. R., Wei, H. H., Qu, Y. Q., Ma, S. X., 2011. Stratigraphic and sedimentary records of the rift to drift evolution of the northern North China craton at the Paleo- to Mesoproterozoic transition. Gondwana Research 1-14. doi:10.1016/j.gr.2010.12.010

Menzies, M., Xu, Y., Zhang, H., Fan, W., 2007. Integration of geology, geophysics and geochemistry: A key to understanding the North China Craton. Lithos 96, 1-21. doi:10.1016/j.lithos.2006.09.008

Paterson, S. R., Ducea, M. N., 2015. Arc Magmatic Tempos: Gathering the Evidence. Elements 11, 91-98. doi:10.2113/gselements.11.2.91

Rudnick, R. L., 1995. Making continental crust. Nature 378, 571-578. doi:10.1038/378571a0

Teng, X., Yang, Q. Y., Santosh, M., 2015. Devonian magmatism associated with arc-continent collision in the northern North China Craton: Evidence from the Longwangmiao ultramafic intrusion in the Damiao area. Journal of Asian Earth Sciences 113, 626-643. doi:10.1016/j.jseaes.2015.04.032

Van der Voo, R., van Hinsbergen, D. J. J., Domeier, M., Spakman, W., Torsvik, T. H., 2015. Latest Jurassicearliest Cretaceous closure of the Mongol-Okhotsk Ocean: A paleomagnetic and seismological-tomographic analysis, in: Late Jurassic Margin of Laurasia-a Record of Faulting Accommodating Plate Rotation, Geological Society of America Special Papers. Geological Society of America, pp. 589-606. 
doi:10.1130/2015.2513(19)

Wan, Y. S., Liu, D. Y., Dong, C. Y., Nutman, A., 2009. The oldest rocks and zircons in China. Acta Petrologica Sinica 25, pp. 1793-1807. (In Chinese with English abstract)

Wang, Y., Zhou, L., Zhao, L., Ji, M., Gao, H., 2010. Palaeozoic uplands and unconformity in the North China Block: constraints from zircon LA-ICP-MS dating and geochemical analysis of Bauxite. Terra Nova. doi:10.1111/j.1365-3121.2010.00942.x

Wang, Y. F., Li, X. H., Jin, W., Zhang, J. H., 2015. Eoarchean ultra-depleted mantle domains inferred from ca. 3.81Ga Anshan trondhjemitic gneisses, North China Craton. Precambrian Research 263, 88-107. doi:10.1016/j.precamres.2015.03.005

Wu, F., Lin, J., Wilde, S., Zhang, X. H., Yang, J., 2005. Nature and significance of the Early Cretaceous giant igneous event in eastern China. Earth and Planetary Science Letters 233, 103-119. doi:10.1016/j.epsl.2005.02.019

Wu, F. Y., Sun, D. Y., Ge, W. C., Zhang, Y. B., Grant, M.L., Wilde, S.A., Jahn, B.-M., 2011. Geochronology of the Phanerozoic granitoids in northeastern China. Journal of Asian Earth Sciences 41, 1-30. doi:10.1016/j.jseaes.2010.11.014

Xiao, W., Windley, B. F., Hao, J., Zhai, M., 2003. Accretion leading to collision and the Permian Solonker suture, Inner Mongolia, China: Termination of the central Asian orogenic belt. Tectonics 22, 1069. doi:10.1029/2002TC001484

Xu, W. L., Pei, F. P., Wang, F., Meng, E., Ji, W. Q., Yang, D.-B., Wang, W., 2013. Spatial-temporal relationships of Mesozoic volcanic rocks in NE China: Constraints on tectonic overprinting and transformations between multiple tectonic regimes. Journal of Asian Earth Sciences 74, 167-193. doi:10.1016/j.jseaes.2013.04.003

Yang, F., Wu, H., Pirajno, F., Ma, B., Xia, H., Deng, H., 2007. The Jiashan Syenite in northern Hebei: A record of lithospheric thinning in the Yanshan Intracontinental Orogenic Belt. Journal of Asian Earth Sciences 29, 619-636. doi:10.1016/j.jseaes.2006.04.005

Yang, J., Wu, F., Shao, J., Wilde, S., Xie, L., Liu, X., 2006. Constraints on the timing of uplift of the Yanshan Fold and Thrust Belt, North China. Earth and Planetary Science Letters 246, 336-352. doi:10.1016/j.eps1.2006.04.029

Yang, J. H., O'Reilly, S., Walker, R. J., Griffin, W., Wu, F. Y., Zhang, M., Pearson, N., 2010. Diachronous decratonization of the Sino-Korean craton: Geochemistry of mantle xenoliths from North Korea. Geol 38, 799-802. doi:10.1130/G30944.1

Yang, J. H., Sun, J. F., Zhang, J. H., Wilde, S. A., 2012a. Petrogenesis of Late Triassic intrusive rocks in the northern Liaodong Peninsula related to decratonization of the North China Craton: Zircon $\mathrm{U}-\mathrm{Pb}$ age and $\mathrm{Hf}-$ O isotope evidence. Lithos 153, 108-128. doi:10.1016/j.lithos.2012.06.023

Yang, J. H., Sun, J. F., Zhang, M., Wu, F. Y., Wilde, S. A., 2012b. Petrogenesis of silica-saturated and silicaundersaturated syenites in the northern North China Craton related to post-collisional and intraplate extension. Chemical Geology 328, 149-167. doi:10.1016/j.chemgeo.2011.09.011

Yang, Y. T., 2013. An unrecognized major collision of the Okhotomorsk Block with East Asia during the Late Cretaceous, constraints on the plate reorganization of the Northwest Pacific. Earth Science Reviews 126, 120. doi:10.1016/j.earscirev.2013.07.010

Ye, H., Zhang, S. H., Zhao, Y., Ye, H., Zhang, S. H., 2014. Origin of two contrasting latest Permian-Triassic volcanic rock suites in the northern North China Craton: implications for early Mesozoic lithosphere thinning. International Geology Review 56, 1630-1657. doi:10.1080/00206814.2014.951979

Zandt, G., Gilbert, H., Owens, T. J., Ducea, M., Saleeby, J., 2004. Active foundering of a continental arc root beneath the southern Sierra Nevada in California. Nature 431, 41-46. doi:10.1038/nature02847

Zhang, C, Wu, G., Wang, G., Zhang, W., Song, H., 2004. Northwest trending tectonic belt in the middle Yanshan Orogenic Belt of northeast Hebei Province, North China: Tectonic evolution and geochronology. Science in China Series D: Earth Sciences 47, 896-911. doi:10.1360/03yd0073

Zhang, S. H., Zhao, Y., 2013. Mid-crustal emplacement and deformation of plutons in an Andean-style continental arc along the northern margin of the North China Block and tectonic implications. Tectonophysics 608, 176-195. doi:10.1016/j.tecto.2013.09.036

Zhang, S. H., Zhao, Y., Kröner, A., Liu, X.-M., Xie, L.-W., Chen, F.-K., 2009a. Early Permian plutons from the northern North China Block: constraints on continental arc evolution and convergent margin magmatism related to the Central Asian Orogenic Belt. International Journal of Earth Sciences 98, 1441-1467. doi:10.1007/s00531-008-0368-2 
600

601

602

603

604

605

606

607

608

609

610

611

612

613

614

615

616

617

618

619

620

621

622

623

624

625
Zhang, S. H., Zhao, Y., Song, B., Liu, D.-Y., 2007. Petrogenesis of the Middle Devonian Gushan diorite pluton on the northern margin of the North China block and its tectonic implications. Geol. Mag. 144, 553-568. doi:10.1017/S0016756807003275

Zhang, S. H., Zhao, Y., Yang, Z.-Y., He, Z.-F., Wu, H., 2009b. The 1.35 Ga diabase sills from the northern North China Craton: Implications for breakup of the Columbia (Nuna) supercontinent. Earth and Planetary Science Letters 288, 588-600. doi:10.1016/j.eps1.2009.10.023

Zhang, Shihong, Gao, R., Li, H., Hou, H., Wu, H., Li, Q., Yang, K., Li, C., Li, W., Zhang, J., Yang, T., Keller, G.R., Liu, M., 2014. Crustal structures revealed from a deep seismic reflection profile across the Solonker suture zone of the Central Asian Orogenic Belt, northern China: An integrated interpretation. Tectonophysics 612-613, 26-39. doi:10.1016/j.tecto.2013.11.035

Zhang, S. H., Zhao, Y., Ye, H., Hou, K. J., Li, C. F., 2012. Early Mesozoic alkaline complexes in the northern North China Craton: Implications for cratonic lithospheric destruction. Lithos 155, 1-18. doi:10.1016/j.lithos.2012.08.009

Zhang, Shuanhong, Zhao, Y., Ye, H., Liu, J. M., Hu, Z. C., 2014. Origin and evolution of the Bainaimiao arc belt: Implications for crustal growth in the southern Central Asian orogenic belt. Geological Society of America Bulletin 126, 1275-1300. doi:10.1130/B31042.1

Zhang, X. H., Zhang, H., Jiang, N., Zhai, M., Zhang, Y., 2010. Early Devonian alkaline intrusive complex from the northern North China craton: a petrological monitor of post-collisional tectonics. Journal of the Geological Society 167, 717-730. doi:10.1144/0016-76492009-110

Zhao, G. C., 2001. Palaeoproterozoic assembly of the North China craton. Geol. Mag. 138, 87-91.

Zhao, G. C., 2013. Precambrian Evolution of the North China Craton. Elsevier Inc. doi:10.1016/B978-0-12407227-5.00006-7

Zhou, X., Sun, T., Shen, W., Shu, L., Niu, Y., 2006. Petrogenesis of Mesozoic granitoids and volcanic rocks in South China: A response to tectonic evolution. Episodes 29, 26-33. 
Middle Devonian- earliest Carboniferous

(380 Ma peak) crutar natering and

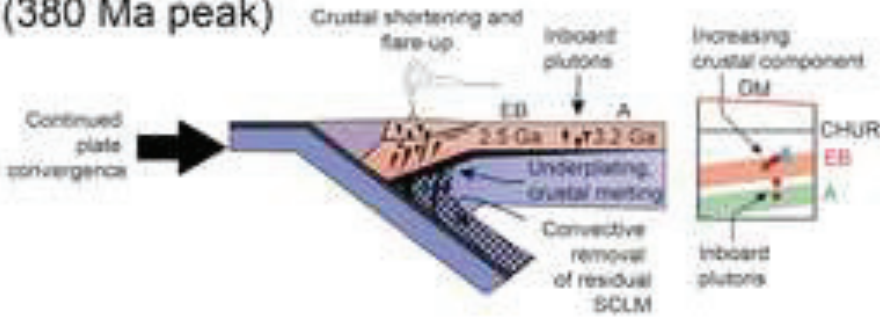

earliest Permian ( 290 Ma)

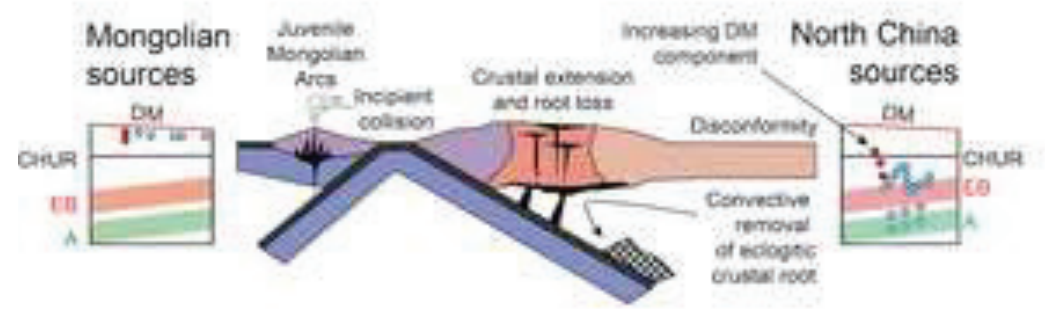

earliest Carboniferous ( $\sim 350 \mathrm{Ma})$
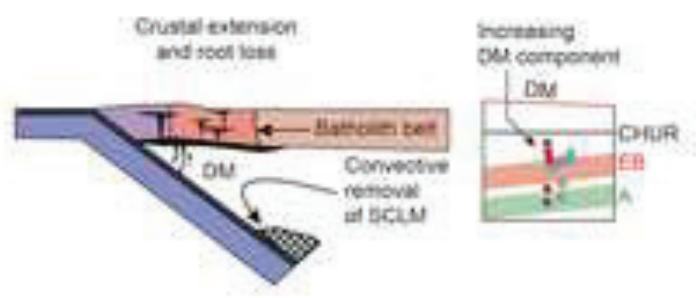

Permian-Triassic (260 Ma peak)

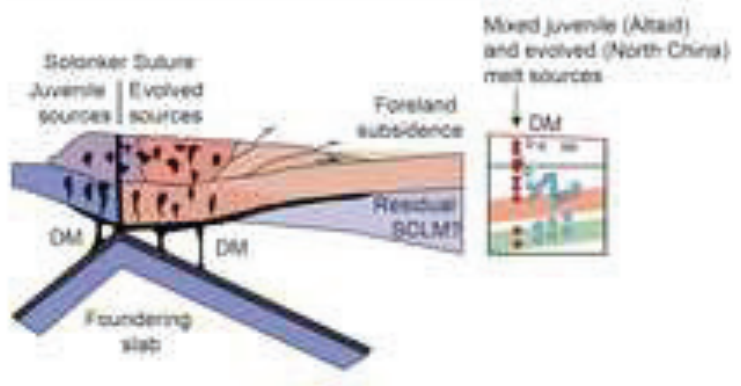

Carboniferous (320 Ma peak)
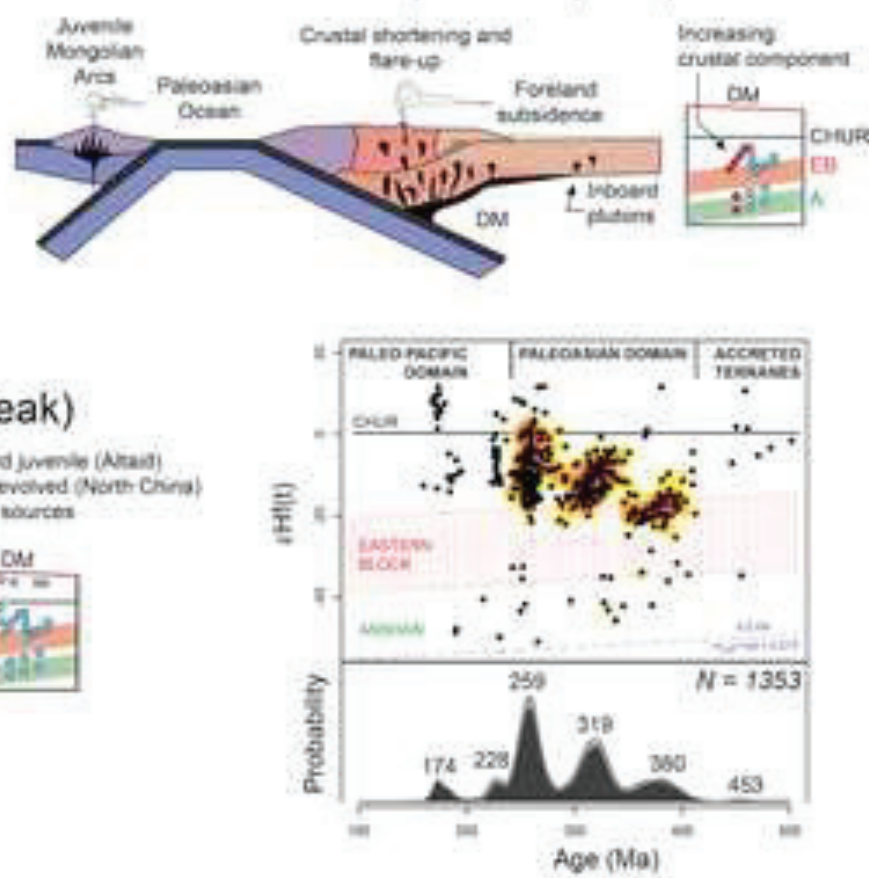


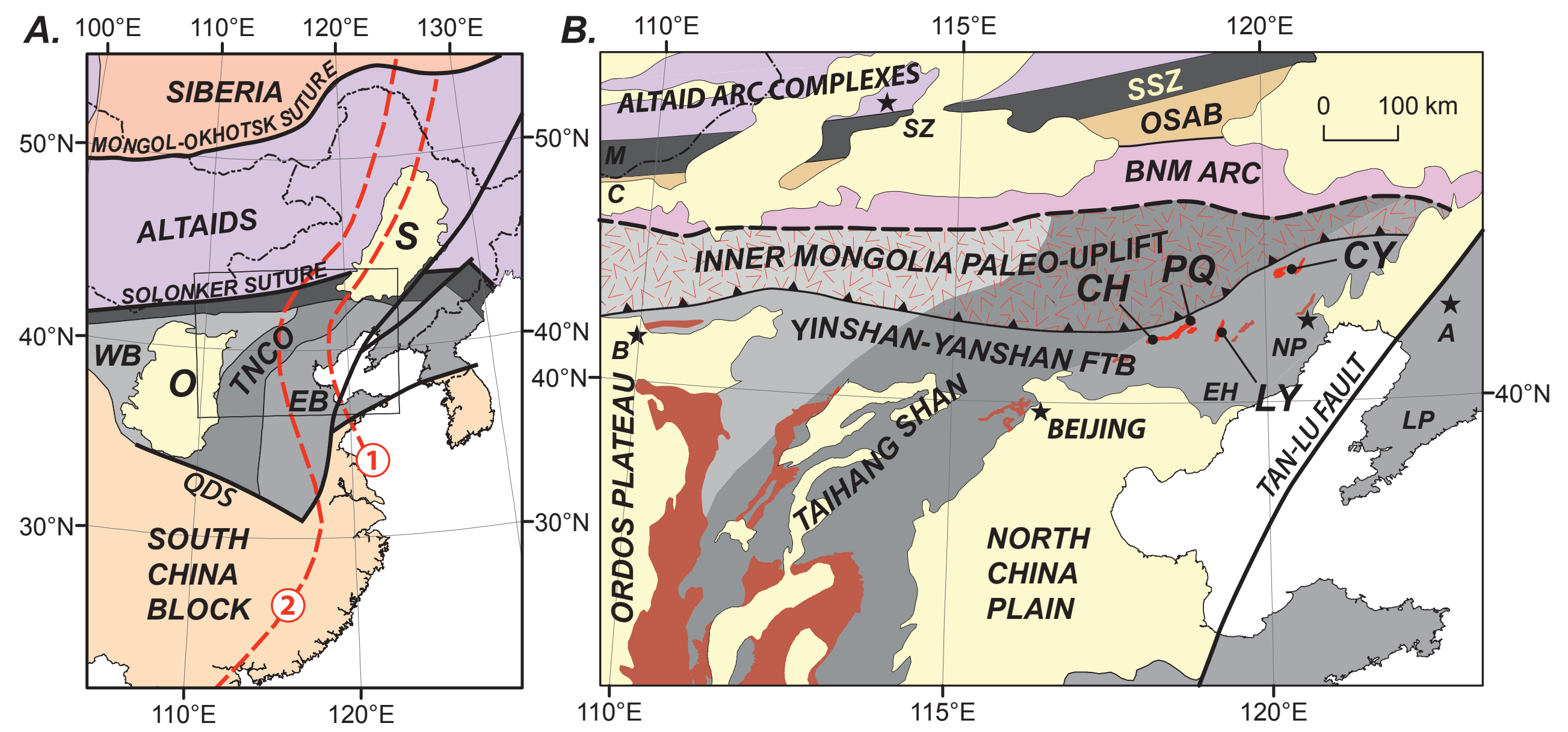




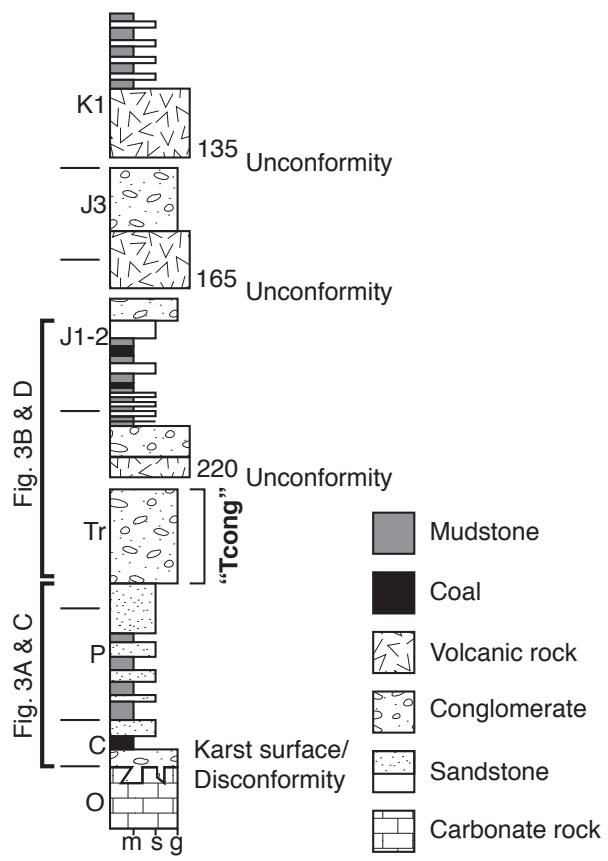




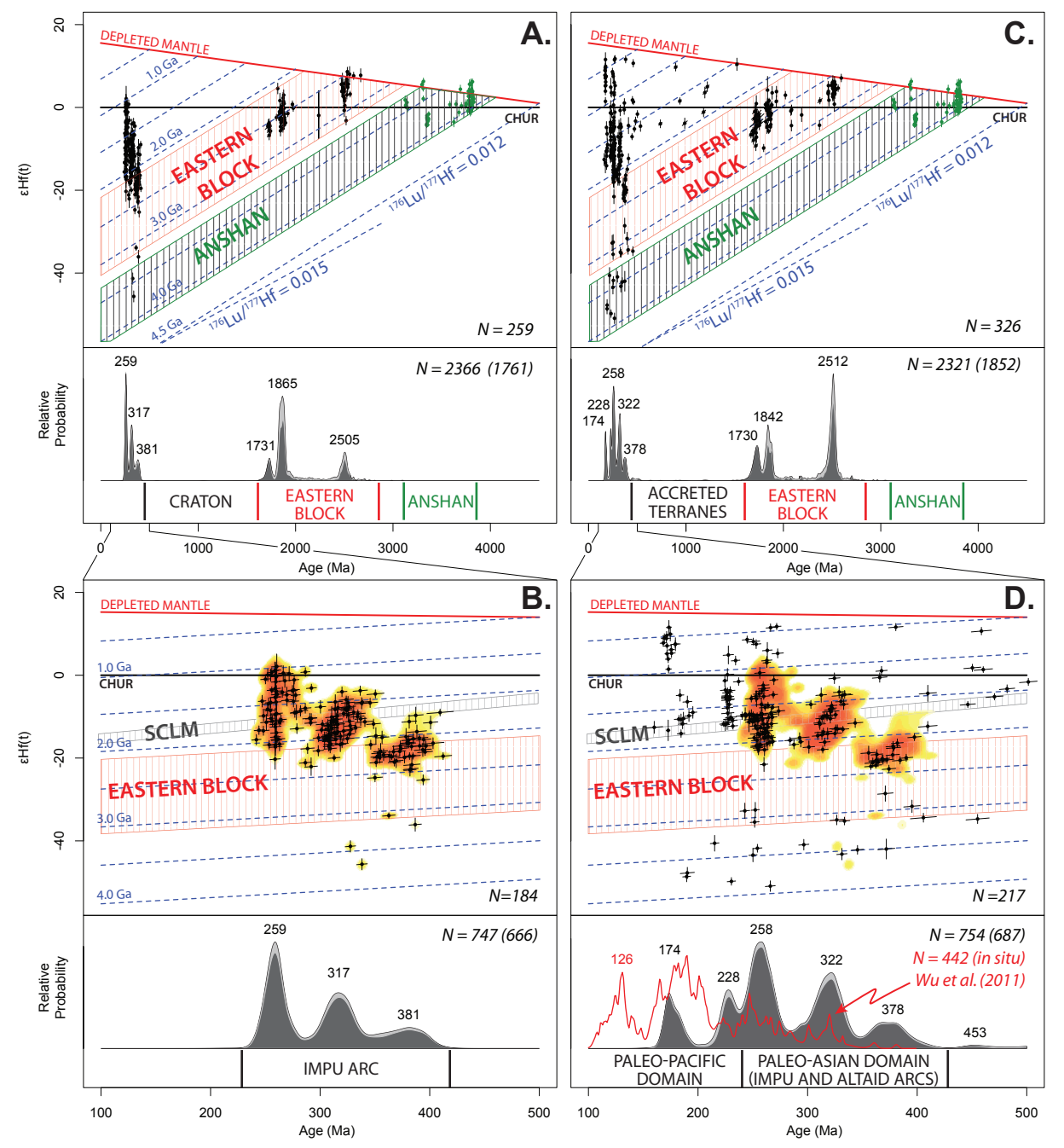




\section{Figure 5}

Click here to download Figure: Fig05.pdf

Pre-Devonian

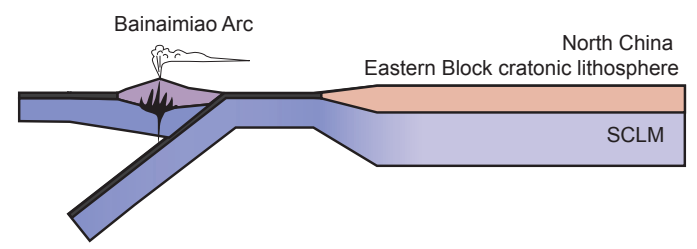

Late Silurian-Early Devonian

\section{Early-Middle Devonian}

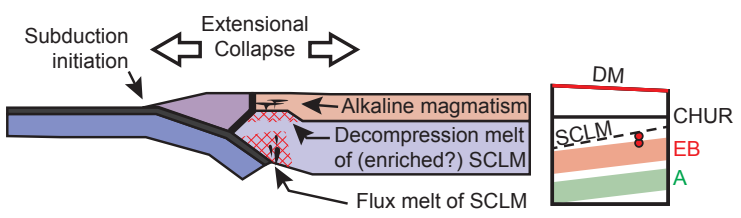

earliest Carboniferous ( $350 \mathrm{Ma})$
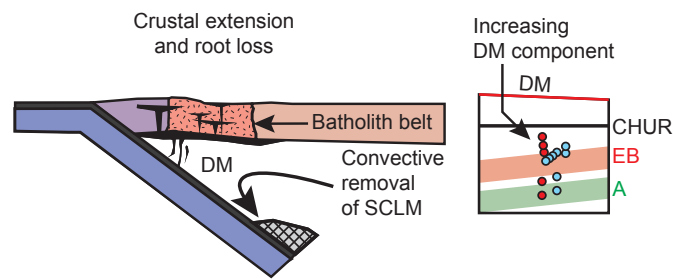

earliest Permian ( 290 Ma)

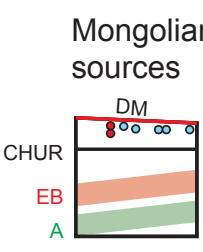

$$
\begin{aligned}
& \text { Juvenile } \\
& \text { Mongolian } \\
& \text { Arcs }
\end{aligned}
$$

Increasing DM component

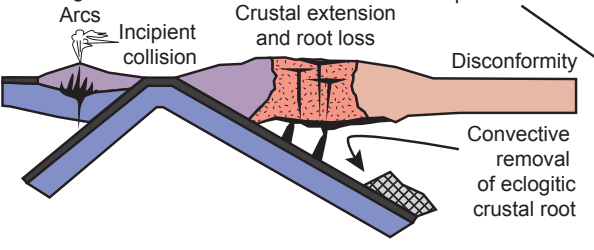

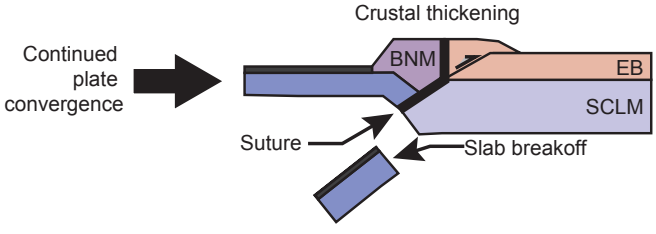

Middle Devonian- earliest Carboniferous (380 Ma peak) crustal shortening and

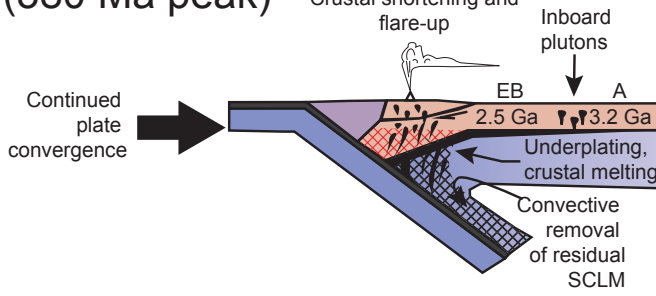

Increasing crustal component

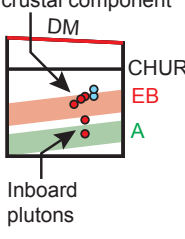

\section{Carboniferous (320 Ma peak)}

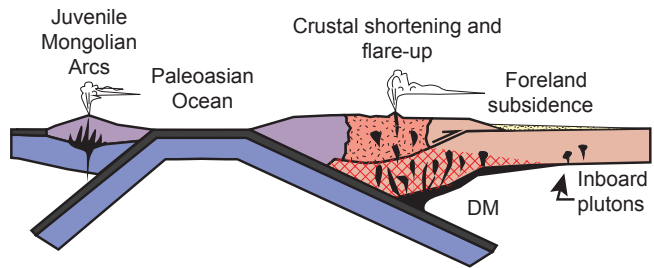

Increasing

crustal component

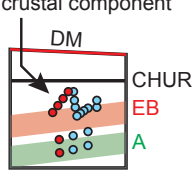

\section{Permian-Triassic (260 Ma peak)}

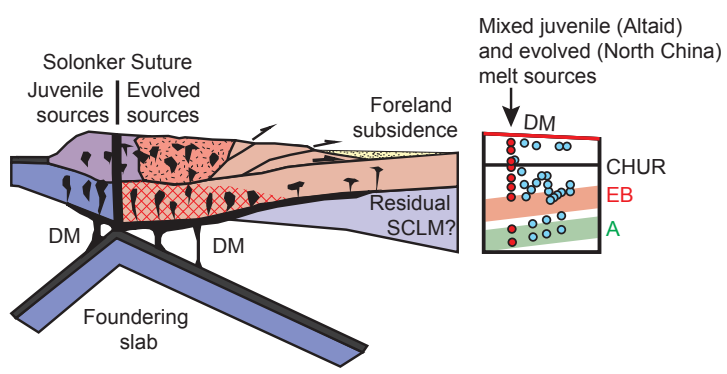

$\checkmark \mathrm{DM}$ CHUR sources

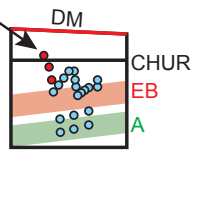

$$
\text { ( }
$$

